\title{
Pengembangan kamus daring bahasa Prancis-Indonesia bidang pariwisata berbasis blog interaktif
}

\author{
Setia Rini, Nani Kusrini \\ 1,2Universitas Lampung \\ ${ }^{1}$ Correspondence: setiarini99@yahoo.fr
}

\begin{abstract}
The industrial revolution 4.0 has given many great impacts in all aspects, either positive or negative. In areas of education, there are many things that have changed, it is more modern and efficient thanks to technology, there is no limitation of time and place. The learning process at all levels has already used various innovative learning media and digital media. In addition, the use of the Internet for learning and teaching purposes is used more from time to time. In this era, all things integrate with the internet (internet of things), this condition then stimulates all people to be more creative to take advantage of the internet in the way of producing or creating a creation. This can be used by many people like the application, the site, the web, etc. Consequently, based on the previous research, we therefore make a development of our research result to be more efficient, more modern and which is suitable with the condition of the era. The French-Indonesian digital dictionary on tourism in 2018, we are developing it by adding more data and also applications for all users. We therefore hope that this digital dictionary can help and be used by many people who learn French, especially in the field of tourism.
\end{abstract}

Keywords: online dictionary, French-Indonesian, tourism

\begin{abstract}
Abstrak
Revolusi Industri 4.0 telah memberikan dampak yang luar biasa di segala bidang baik dampak positif maupun negatif. Dunia pendidikan pun semakin bertransformasi ke arah yang lebih modern dan efektif, tidak terbatas oleh ruang dan waktu. Proses pembelajaran di semua jenjang didukung dengan berbagai macam media pembelajaran yang inovatif dan berbasis TIK. Pemanfaatan internet untuk segala keperluan pendidikan dan pengajaran semakin gencar digunakan. Era mileneal yang mana segala sesuatu terintegrasi oleh internet (internet of things) telah memaksa dan menstimulasi orang-orang untuk kreatif memanfaatkan internet dengan menghasilkan sebuah karya yang dapat digunakan dan diakses oleh banyak orang, seperti aplikasi, situs, web, dan lain-lain. Dengan demikian, berdasarkan hasil penelitian sebelumnya yang telah dilakukan oleh peneliti, maka peneliti mengembangkan kembali hasil penelitian tersebut menjadi lebih efektif, lebih modern dan tentu saja
\end{abstract}


sesuai dengan eranya. Kamus daring bahasa Prancis-Indonesia bidang pariwisata yang telah dibuat pada tahun 2018, dikembangkan menjadi kamus daring bahasa Prancis-Indonesia bidang pariwisata berbasis blog interaktif. Pengembangan kamus ini diharapkan dapat lebih komunikatif untuk digunakan dengan konten yang lebih banyak dan variatif. Oleh karena itu, para pembelajar bahasa Prancis khususnya bidang pariwisata akan semakin terbantu dan terfasilitasi dengan adanya kamus digital tersebut.

Kata kunci: kamus daring, bahasa Prancis-Indonesia, bidang pariwisata

\section{Pendahuluan}

Era revolusi industri 4.0 telah memberikan peluang sekaligus tantangan baru di segala bidang kehidupan. Revolusi industri 4.0 yang ditandai dengan penggunaan dan pemanfaatan internet dalam segala bidang (internet of things) mendorong manusia untuk semakin cerdas, aktif, inovatif dan efisien. Saat ini, banyak hal atau pekerjaan yang dapat dikerjakan oleh teknologi, informasi dapat dengan mudah dicari melalui internet, bahkan data-data sebanyak apapun dapat disimpan di komputer dan diintegrasikan dengan internet dengan mudah, tidak terbatas oleh ruang dan waktu. Era revolusi industri 4.0 merupakan era di mana hidup manusia berorientasi pada teknologi (Maemunah, et al., $2018:$ 85). Percepatan di bidang ilmu pengetahuan dan teknologi, sistem komunikasi seperti mudahnya akses internet menjadi salah satu ciri abad 21, dunia seakan-akan menjadi kecil dan berada dalam genggaman, apa yang terjadi diujung dunia sana, akan dengan mudah diketahui oleh orang yang berada di ujung dunia yang lain, dalam waktu yang bersamaan, berbagai teknologi canggih yang pada intinya untuk mempermudah segala macam urusan manusia ditemukan, dikembangkan, dibuat dan dipakai oleh banyak orang dengan biaya yang sangat terjangkau, (Maemunah, $2018: 1$ ).

Bahkan dunia pendidikan juga semakin berkembang sebagai dampak positif dari era revolusi industri 4.0 atau era teknologi digital. Perkembangan teknologi digital telah mendisrupsi berbagai aktivitas manusia, tidak hanya sebagai mesin penggerak ekonomi namun juga termasuk bidang ilmu pengetahuan dan teknologi (iptek) serta pendidikan tinggi, (Maemunah, 2018 : 1). Proses pembelajaran dan pengajaran di berbagai jenjang pendidikan semakin canggih tidak terbatas oleh ruang dan waktu, mahasiswa dapat melakukan perkuliahan tanpa harus datang ke kampus (kuliah jarak jauh, blended learning, e-learning, dan lain-lain). Dosen dapat memberikan tugas perkuliahan dengan memanfaatkan sosial media, sehingga mahasiswa pun menjadi semakin antusias untuk mengerjakan tugas. Dosen dan mahasiswa juga dapat menggunakan berbagai macam media pembelajaran berbasis TIK 
seperti berbagai macam aplikasi pembelajaran berbasis android, berbagai situs/ web/ blog pembelajaran di internet, dan berbagai macam informasi yang berkaitan dengan materi perkuliahan, ilmu pengetahuan dan lain-lain yang juga dapat dengan mudah diakses melalui internet. Sangat penting bagi seorang pengajar maupun pembelajar untuk menggunakan media pembelajaran yang menarik dan efektif untuk mendukung proses pembelajaran sebagai salah satu komponen penting dalam proses pembelajaran, (Rini \& Rosita, 2019: 164).

Dengan demikian, tren penggunaan sistem digital berbasis internet merupakan salah satu karakteristik kehadiran era revolusi industri ke empat, (Regina \& Annisa, 2019 :183). Oleh karena itu, aktivitas dan kegiatan pengajaran dan pembelajaran pun juga tidak terlepas dari penggunaan internet. Peneliti dapat mengatakan bahwa, segala kegiatan tersebut terintegrasi oleh internet. Para akademisi yang sadar akan tantangan dan peluang hadirnya Revolusi Industri 4.0, akan dengan cepat merespon dan melakukan perubahanperubahan yang signifikan dalam proses pembelajaran atau perkuliahan. Era Revolusi Industri 4.0 ditandai dengan adanya penggunaan teknologi dalam membantu segala aktivitas manusia. Kemunculan era ini akrab kaitannya dengan penggunaan internet of things (IoT) pada berbagai aspek kehidupan, begitu juga pada dunia pendidikan (Shofa, 2019 : 20). Tidak hanya memanfaatkan referensi dalam media cetak tetapi juga media online, tidak hanya memberikan tugas atau materi perkuliahan secara langsung tetapi mulai menggunakan internet, media sosial, google classroom, dan lain-lain. Seorang dosen tidak hanya menggunakan media pembelajaran manual atau tradisional, tetapi juga media pembelajaran inovatif berbasis TIK atau internet. Bahkan saat ini, gawai pintar (smartphone) pun juga dimanfaatkan dalam proses pembelajaran baik di dalam maupun di luar kelas. Penggunaan smartphone sudah menjadi pemandangan umum masyarakat kita, tidak peduli dari kalangan mana, dengan latar belakang pekerjaan apa pun, bahkan dari golongan usia manapun (Syamsur \& Reflianto, 2019:4).

Oleh karena itu, menjawab tantangan sekaligus peluang Revolusi Industri 4.o, peneliti mengembangkan hasil penelitian sebelumnya yaitu kamus daring bahasa Prancis-Indonesia bidang pariwisata menjadi kamus daring bahasa Prancis-Indonesia bidang pariwisata berbasis blog interaktif. Sasaran dari produk penelitian ini adalah mahasiswa pada khususnya dan publik yang ingin belajar bahasa Prancis bidang pariwisata pada umumnya. Kamus merupakan instrumen penting bagi orang-orang yang berkecimpung di bidang bahasa, terutama dalam ranah akademik. Dalam proses pembelajaran bahasa, kamus menjadi media pendukung, baik bagi pendidik maupun peserta didik, (Utami, et al., 2019 : 46). Dengan demikian, kehadiran kamus tersebut diharapkan dapat menjadi angin segar bagi para pembelajar bahasa Prancis khususnya di bidang pariwisata, karena referensi berbahasa Prancis bidang 
pariwisata masih sangat sulit diperoleh. Dengan demikian, kamus daring atau kamus digital tersebut diharapkan dapat membantu dan mempermudah mahasiswa karena dapat diakses di mana pun dan kapan pun dengan data dan konten yang lebih lengkap dibandingkan kamus daring sebelumnya.

Berdasarkan beberapa hal tersebut di atas, maka rumusan masalah dari penelitian ini adalah :

1. Apakah pengembangan kamus daring bahasa Prancis-Indonesia bidang pariwisata berbasis blog interaktif dapat lebih membantu dan menfasilitasi mahasiswa khususnya di bidang pariwisata?

2. Apakah kamus daring bahasa Prancis-Indonesia bidang pariwisata berbasis blog interaktif dapat membantu dan memfasilitasi publik yang mempelajari bahasa Prancis bidang pariwisata?

3. Apa kelebihan kamus daring bahasa Prancis-Indonesia bidang pariwisata berbasis blog interaktif tersebut?

4. Apa kekurangan kamus daring bahasa Prancis-Indonesia bidang pariwisata berbasis blog interaktif tersebut?

\section{Kajian pustaka \\ Revolusi industri 4.0}

Telah diungkapkan sebelumnya oleh peneliti bahwa Revolusi Industri 4.o merupakan era mileneal, era teknologi, dan juga era internet. Artinya, manusia dalam segala aktivitas kehidupannya selalu terintegrasi dengan teknologi dan internet. Di berbagai bidang kehidupan baik ekonomi, sosial, kesehatan, politik bahkan pendidikan terkoneksi dan terintegrasi dengan internet. Selain itu, Revolusi Industri 4.0 juga disebut dengan revolusi digital dan era disrupsi. Disebut revolusi digital karena terjadinya proliferasi komputer dan otomatisasi pencatatan di semua bidang. Industri 4.0 dikatakan era disrupsi teknologi karena otomatisasi dan konektivitas di sebuah bidang akan membuat pergerakan dunia industri dan persaingan kerja menjadi tidak linear (Muhammad, 2018 : 5-6). Di sisi lain, Syamsuar dan Reflianto (2019: 2) menambahkan, secara umum definisi revolusi industri adalah ketika kemajuan teknologi yang besar disertai dengan perubahan sosial ekonomi dan budaya yang signifikan. Revolusi Industri 4.0 mulai muncul pada saat teknologi internet mulai berkembang dan memberikan perubahan besar ke dalam setiap aspek kehidupan. Salah satunya dalam kehidupan sosial, seperti akses komunikasi menjadi lebih mudah dan efisien dengan adanya Whatsapp, Facebook, Twitter, dan lain sebagainya. Contoh lain adalah menjamurnya $e^{-}$ commerse seperti amazon, Buka Lapak, Kaskus, Shopee, dan lain sebagainya yang memudahkan dalam proses jual beli. Penggunaan Internet of Thing bahkan digunakan pula pada bidang transportasi, seperti adanya aplikasi Go- 
Jek, Grab, dan aplikasi lainnya yang memudahkan pengemudi dan juga penumpang yang menggunakan jasa tersebut (Kurnia \& Fitriyani, $2018: 100$ ).

Di sisi lain, di bidang pendidikan tentu saja Revolusi Industri juga memberikan dampak yang luar biasa baik dampak positif maupun negatif. Revolusi Industri 4.0 memberikan peluang juga tantangan bagi dunia pendidikan, bagi guru, siswa, dosen, mahasiswa, juga para akademisi dan pengembang kurikulum pada khususnya. Shofa (2019: 20) mengungkapkan bahwa era Revolusi Industri 4.0 menuntut dunia pendidikan bertransformasi dalam berbagai aspek. Dalam rangka merespon kemajuan teknologi tersebut, kurikulum pembelajaran didorong untuk melakukan transformasi yaitu kurikulum pembelajaran perlu menggunakan media pembelajaran yang berbasis internet.

Dengan demikian, Revolusi Industri 4.o dapat disimpulkan oleh peneliti sebagai masa/ era/ zaman di mana kehidupan dan aktivitas manusia tidak terlepas dari teknologi dan internet. Dan hal tersebut memberikan dampak, baik tantangan maupun peluang bagi dunia pendidikan pada khususnya. Proses pembelajaran, strategi pembelajaran, materi pembelajaran, media pembelajaran dan juga proses evaluasi pembelajaran pun dapat dengan mudah diakses melalui internet.

\section{Bahasa Prancis bidang pariwisata (Français du tourisme)}

Bahasa Prancis sebagai bahasa asing memiliki beberapa bidang keilmuan yang spesifik. Seseorang dapat mempelajari bahasa Prancis sebagai bahasa asing (Français Langue Étrangère) pada umumnya, atau pun mendalami bahasa Prancis di bidang khusus (Français sur les Objectifs Spécifiques) seperti bidang pariwisata, perhotelan, kesehatan, dan lain-lain. Qobt (2008) menjelaskan bahwa ada beberapa bidang bahasa Prancis yang termasuk ke dalam bahasa Prancis bidang khusus yaitu bahasa Prancis bidang perusahaan dan bisnis (le français des affaires), bidang perhotelan (le français de l'hôtellerie), bidang pariwisata (le français du tourisme), bidang ilmu pengetahuan dan teknik (le français scientifique et technique), bidang hukum (le français juridique), bidang hubungan internasional (le français des relations internationnelles), bidang kedokteran (le français de la médecine), bidang relasi publik dan administrasi (le français des relations publiques et de l'administration), bidang kesekretariatan (le français du secrétariat), bidang ilmu sosial (le français des sciences sociales et humaines), bidang informasi (le français de l'informatique), bidang jurnalistik (le français journalistique), bidang makanan (le français la gastronomie), dan lain-lain.

Bahasa Prancis bidang pariwisata dapat diartikan sebagai bidang bahasa Prancis yang khusus hanya mempelajari bidang pariwisata. Pariwisata sendiri menurut KBBI daring bermakna hal/kegiatan yang berhubungan dengan 
perjalanan untuk rekreasi, pelancongan, turisme. Di sisi lain, Organisasi Pariwisata Dunia mendefinisikan pariwisata sebagai : Les activités déployées par les personnes au cours de leurs voyages et de leurs séjours dans les lieux situés en dehors de leur environnement habituel pour une période consécutive qui ne dépasse pas une année à des fins de loisirs, pour affaires et autres motifs, (OMT, 2010: 16). Pendapat tersebut dapat diartikan bahwa pariwisata adalah aktivitas yang dilakukan orang selama perjalanan dan tinggal di tempat tertentu yang biasanya untuk jangka waktu tidak lebih dari satu tahun berturutturut, seperti untuk liburan, bisnis, dan keperluan lain. Dengan demikian dapat disimpulkan bahwa bahasa Prancis bidang pariwisata merupakan bahasa Prancis bidang khusus yang mempelajari tentang segala hal yang berkaitan dengan kegiatan wisata, perjalanan dan liburan. Dengan demikian, bahasa Prancis bidang pariwisata (français du tourisme) mempelajari khusus bidang pariwisata baik secara keilmuan/teori, kosakata, dan segala hal yang berkaitan dengan pariwisata dan kompetensi-kompetensi yang perlu dikuasai di bidang pariwisata. Artinya, bagaimana bekal untuk menjadi pemandu wisata, agen wisata, agen perjalanan, dan lain-lain diperoleh melalui bahasa Prancis khusus tersebut.

\section{Cakupan materi bahasa Prancis bidang pariwisata}

Berdasarkan silabus mata kuliah Français du Tourisme di Program Studi Pendidikan Bahasa Prancis Jurusan Pendidikan Bahasa dan Seni Universitas Lampung, materi-materi yang dipelajari di dalam mata kuliah tersebut diantaranya berkaitan dengan : pemesanan tiket, jadwal penerbangan, kosakata penerbangan, rencana penerbangan, pemesanan tiket, pemesanan hotel, publikasi hotel, restoran, menu makanan, liburan, agen perjalanan, tempattempat wisata, dan lain-lain. Sedangkan untuk materi bahasa Prancis bidang pariwisata yang terdapat di dalam silabus mata kuliah Français du Tourisme Departemen Pendidikan Bahasa Prancis UPI mencakup beberapa hal : penerimaan tamu (accueil), hiburan (animation), promosi wisata (promotion d'une destination), agen wisata (vente d'un produit touristique), dan pemandu wisata (guide touristique) yang dipecah menjadi materi-materi kecil seperti : se présenter et parler de son métier, présenter son entreprise, engager une conversation téléphonique, prendre contact par écrit, renseigner à l'aéroport, accueillir les passagers, informer les voyageurs, vendre un billet de train, etablir un programme d'animation, animer un village de vacances, renseigner sur les manifestations, evaluer une animation, informer à l'office du tourisme, traiter de demande écrit, promouvoir un site touristique, des brochures pour informer, identifier les produits touristiques, rédiger un circuit, mener un entretien de vente, annuler une réservation, s'informer pour bien guider, visiter la ville, présenter un monument dan gérer un groupe. 
Di sisi lain, cakupan materi bahasa Prancis bidang pariwisata di dalam buku ajar bahasa Prancis bidang pariwisata oleh Viret (2012: 6) mencakup beberapa materi berikut ini : les métiers du tourisme, les types de tourisme, conseils aux voyageurs, promotion touristique, conception et commercialisation, dan accueil et animation. Oleh karena itu, dari beberapa cakupan materi yang dipelajari dalam bahasa Prancis bidang pariwisata menurut beberapa teori di atas, dapat disimpulkan bahwa materi-materi yang dipelajari merupakan materi yang tentu saja berkaitan dengan kegiatan pariwisata, termasuk pekerjaan-pekerjaan di bidang pariwisata, kosakata khusus di bidang pariwisata termasuk hal lain yang berkaiatan dengan pariwisata seperti restoran, makanan dan minuman, hotel, penerbangan, tempat wisata, dan lain-lain.

\section{Kamus daring}

Menurut Wiliam (2011), kamus daring merupakan situs web yang menyediakan layanan menterjemahkan kata/kalimat layaknya kamus yang ada di toko buku, yang mana kita dapat mengubah suatu kata dalam satu bahasa ke bahasa yang lain, atau juga memberikan layanan pengertian atau makna dari suatu kata. Artinya kamus yang dimaksud adalah kamus pada umunya tetapi bersifat daring atau online. Merujuk pada definisi tersebut, seseorang yang mempelajari bahasa asing biasanya membutuhkan alat bantu dalam hal ini kamus, yang dapat memudahkan mereka untuk mencari kosakata yang tidak mereka tahu. Kamus merupakan instrumen penting bagi orang-orang yang berkecimpung di bidang bahasa, terutama dalam ranah akademik. Dalam proses pembelajaran bahasa, kamus menjadi media pendukung, baik bagi pendidik maupun peserta didik, (Utami, et al. 2019: 46).

Perkembangan kamus pun sangat cepat dan signifikan seiring dengan berkembangnya teknologi dan internet. Risdianto (2014: 37-38) mengungkapkan bahwa salah satu sumber belajar yang berkembang seiring dengan perkembangan ilmu pengetahuan dan tekhnologi (IPTEK) adalah kamus. Perkembangan IPTEK membuat kamus tidak selalu berbentuk sebuah buku. Kamus dapat berupa e-book (elektronik book) ataupun aplikasi komputer yang dapat mempermudah peserta didik dan dapat dibawa kemana saja dengan menyimpannya di dalam sebuah removable disk. Jika dulu, kebanyakan orang menggunakan kamus cetak yang biasanya tebal dan berat untuk dibawa, bahkan membutuhkan waktu beberapa lama untuk mencari kosakata yang dimaksud, berbeda halnya dengan perkembangan kamus saat ini. Dampak positif dari adanya Revolusi Industri 4.0, yaitu segala sesuatu yang awalnya berupa referensi atau data cetak, sekarang sudah dapat diinput di komputer dan terintegrasi dengan internet. Dengan demikian akan dengan sangat mudah dan efisien untuk diakses, termasuk kamus itu sendiri. Herriyance, et al. (2017: 65) 
juga menambahkan bahwa setiap bentuk kamus memiliki kelemahan dan juga kelebihan. Contohnya kamus dalam bentuk buku memiliki kelebihan dalam jumlah kata yang banyak, tetapi juga memiliki kelemahan dalam hal pencarian kata, yakni membutuhkan waktu yang lama dalam pencarian serta tidak praktis. Media kamus dalam bentuk mobile kamus bisa dijadikan solusi untuk mengatasi masalah dalam pencarian kata dengan cepat.

Salah satu contoh nyata perkembangan kamus yang benar-benar mengalami metamorfosis dari kamus cetak sampai terbentuk kamus daring adalah Kamus Besar Bahasa Indonesia (KBBI). Kamajaya, et al. (2017: 514) menjelaskan $K B B I$ is the most comprehensive and the most authoritative reference for the Indonesian language. Its latest, fifth edition was released for the first time in 2016 in three formats: printed, online, and offline mobile versions. The new online KBBI called "KBBI Dalam Jaringan" or "KBBI Daring" was launched on 28 October 2016. Penjelasan tersebut dapat diartikan bahwa KBBI merupakan referensi bahasa Indonesia terlengkap yang mana di edisi terakhir (edisi kelima) dipublikasikan untuk pertama kali pada tahun 2016 dalam tiga bentuk : cetak, daring dan aplikasi mobile. Sedangkan untuk KBBI online yang disebut KBBI daring dipublikasikan pada tanggal 28 Oktober 2016. Dengan demikian proses perubahan dan perkembangan KBBI di Indonesia sejak awal sampai dengan saat ini, selalu berupaya untuk mengikuti perkembangan zaman dan teknologi. Jika dulu KBBI hanya dapat diakses melalui KBBI bentuk cetak atau buku, maka di era Revolusi Industri 4.0 saat ini, KBBI dapat dengan mudah diakses oleh siapapun bahkan warga negara asing melalui internet dengan mengakses KBBI daring atau memasang aplikasi KBBI offline di gawai.

Terlepas dari bentuk kamus yang terus mengalami perkembangan, ada hal penting yeng perlu diperhatikan dalam pembuatan kamus itu sendiri. Rachma (2017: 120) mengungkapkan bahwa :

Kamus yang baik tentu saja adalah kamus yang disusun berdasarkan proses yang sesuai serta menggunakan sumber data entri yang tepat. Sumber entri yang di gunakan dalam kamus penting untuk diperhatikan, karena objek utama dalam kamus adalah entri itu sendiri. Menurut Zgusta (1971) penyusunan sebuah kamus bukanlah hal yang mudah. Bahkan dikatakan bahwa ilmu perkamusan merupakan bagian yang sangat sukar yang terdapat dalam praktik linguistik. Sebuah kamus disusun bukan asal disusun saja, melainkan ada tujuannya, yaitu menyangkut masalah kamus itu ditujukan kepada siapa dan seberapa besar ruang lingkupnya (Chaer, 2007:212).

\section{Blog interaktif}

Menurut KBBI daring, blog didefinisikan sebagai catatan harian atau jurnal pribadi di internet yang dapat diakses oleh siapa saja. Blog berasal dari asal kata web blog. Web artinya Internet, dan blog 
artinya adalah catatan. Istilah blog pertama kali digunakan oleh Jorn Barger pada bulan Desember 1997 sebagai kependekan dari weblog. Barger menggunakan istilah weblog untuk menyebut kelompok website pribadi yang selalu diupdate secara berkelanjutan dan berisi link ke website lain yang mereka anggap menarik disertai dengan komentar-komentar mereka sendiri, (Santoso, 2009: 132). Di sisi lain, Wahyudi (2014: 46) menjelaskan bahwa blog merupakan singkatan dari web blog yang artinya adalah suatu bentuk aplikasi/layanan web yang dibuat untuk memudahkan user dalam mempublikasikan informasi yang dimilikinya melalui tulisan-tulisan yang dimuat dalam sebuah postingan. Dengan demikian dapat disimpulkan bahwa blog merupakan sebuah wadah/aplikasi/ sarana tulis yang terintegrasi dengan internet, yang mana pemilik blog dapat mengisi blog tersebut dengan berbagai macam informasi dan dapat diakses oleh para pengguna lain.

Sedangkan interaktif sendiri menurut KBBI didefinisikan sebagai sesuatu yang berkaitan dengan dialog antara komputer dan terminal atau antara komputer dan komputer, atau keadaan yang ditandai dengan pertukaran percakapan dari masukan dan keluaran, seperti ketika pengguna memasukkan pertanyaan atau perintah dan sistem segera memberikan tanggapan. Dengan demikian, blog interaktif dapat peneliti simpulkan sebagai aplikasi untuk memberikan informasi secara tertulis dan berbasis internet yang mana bersifat interaktif, artinya melalui aplikasi tersebut dapat dilakukan sebuah hubungan atau percakapan. Sedangkan yang dimaksud blog interaktif dalam penelitian ini merupakan blog khusus dalam bentuk kamus bahasa Prancis-Indonesia bidang pariwisata yang mana dapat diakses oleh siapapun dan kapanpun. Selain itu, para pengguna blog tersebut dapat melakukan interaksi dengan blog baik bertanya secara tertulis tentang bahasa Prancis bidang pariwisata maupun menuliskan komentar. Selain itu, blog interaktif yang dimaksud dalam penelitian ini juga dilengkapi dengan alamat web/blog lain yang berkaitan dengan bahasa Prancis bidang pariwisata sebagai informasi lanjutan yang lebih lengkap.

\section{Metode}

Berdasarkan tujuan penelitian yang telah dipaparkan, maka peneliti menggunakan metode penelitian R n D (Research and Development) yang mencakup beberapa proses atau tahapan. Secara singkat, tahapan metode penelitian R n D menurut Sugiyono (2011: 409-419) mencakup sepuluh tahapan penting yang ditunjukkan melalui bagan di bawah ini.

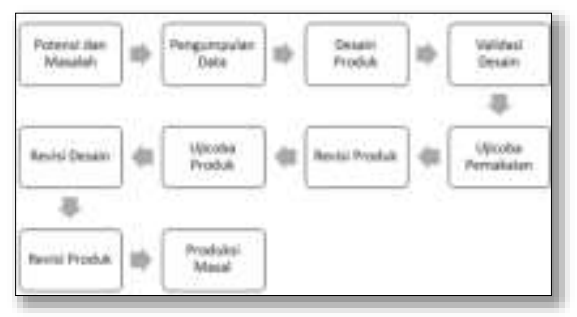


Bagan 1. Tahapan Metode Penelitian R n D

\section{Populasi dan sampel penelitian}

Populasi dari penelitian ini adalah seluruh bentuk kamus daring bahasa Prancis-Indonesia, sedangkan sampel dari penelitian ini adalah kamus daring bahasa Prancis-Indonesia bidang pariwisata berbasis blog interaktif.

\section{Instrumen penelitian}

Arikunto (2002: 126) mendefinisikan instrumen sebagai alat pada waktu penelitian menggunakan sesuatu metode. Dengan demikian, instrumen yang digunakan oleh peneliti mencakup : studi pustaka, leksikografi, dan kamus daring.

\section{Validitas penelitian}

Dalam kegiatan penelitian, perlu adanya validitas penelitian untuk memperoleh data bahwa instrumen-instrumen dan produk yang dihasilkan dalam penelitian adalah valid. Dalam penelitian ini, peneliti menggunakan expert judgement sebagai validitas penelitian, yaitu dosen ahli dibidang bahasa Prancis.

\section{Teknik pengumpulan data}

Pengumpulan data yang dilakukan untuk memperluas data korpus kamus daring, dilakukan dengan studi pustaka terutama dengan memanfaatkan berbagai macam situs internet khususnya di bidang pariwisata. Selain dari berbagai referensi cetak, juga ditambahkan berbagai macam penjelasan dan pemaparan setiap korpus data dengan menyertakan link/situs internet. Oleh karena itu, peneliti masih melakukan beberapa tahapan penting dalam pembuatan kamus seperti di proses awal yaitu mecakup proses pengembangan data korpus, pengurutan alfabetis, analisis data korpus dan pemberian terjemahan juga penambahan link untuk setiap kosakata yang memiliki daftar referensi lebih banyak.

\section{Teknik analisis data}

Teknik analisis data yang digunakan dalam penelitian ini adalah analisis deskriptif kualitatif. Seluruh data yang terkumpul akan dianalisis secara mendalam sehingga diperoleh kesimpulan yang merujuk pada perumusan masalah.

Sedangkan untuk mengetahui hasil angket, peneliti menggunakan rumus berikut ini (Supardi, 1979: 20, dalam Fauzi, 2010) : 
$\%=\frac{f}{N} \times 100 \%$

$\mathrm{f}=$ frekuensi jumlah responden

$\mathrm{N}=$ jumlah responden

$\%=$ persentase frekuensi tiap jawaban responden

Untuk menerjemahkan hasil angket, peneliti akan menggunakan kategori persentase di bawah ini (Sudjana, 1988: 32, dalam Fauzi, 2010) :

$$
\begin{array}{ll}
0 \% & =\text { tidak seorang pun } \\
1-25 \% & =\text { sebagian kecil } \\
26-49 \% & =\text { kurang dari setengah } \\
50 \% & =\text { setengah } \\
51-75 \% & =\text { lebih dari setengah } \\
76-99 \% & =\text { sebagian besar } \\
100 \% & =\text { seluruhnya }
\end{array}
$$

\section{Hasil dan pembahasan}

\section{Pengembangan data korpus kamus daring}

Data korpus yang mencakup kosakata bidang pariwisata yang sudah ada di dalam kamus daring berbasis blog, dikembangkan kembali jumlah data korpusnya juga ditambahkan informasi baru di setiap kosakata tersebut dengan menambahkan link situs internet. Hal ini dimaksudkan untuk semakin mempermudah pengguna dalam menggunakan kamus daring tersebut. Pengguna tidak hanya menemukan terjemahannya dari bahasa Prancis ke dalam bahasa Indonesia, tetapi pengguna juga dapat menemukan informasi lebih lengkap dengan cara mengklik kosakata yang dimaksud. Adapun beberapa contoh tambahan data korpus yang dimaksud, serta link yang menyertainya, peneliti paparkan di bawah ini.

$\mathbf{A}$

Aéroport (n.m) bandara

https://fr.wikipedia.org/wiki/Liste des_a\%C3\%A9roports_fran\%C3\%A7ais_cl ass\%C3\%Ags selon le nombre de mouvements d\%27a\%C3\%Agronef

Alimentation (n.f) makanan

https://www.cuisineaz.com/diaporamas/aliments-les-plus-consommes-en-

france-520/interne/1.aspx

Alpage (n.m) padang rumput (di pegunungan)

https://france3-regions.francetvinfo.fr/auvergne-rhone-

alpes/emissions/chroniques-d-en-haut/actu/la-petite-maison-dans-les-

alpages.html

Atelier (n.m) bengkel; bengkel pengrajin kayu 
https://www.lebonbon.fr/paris/loisirs/les-plus-belles-demeures-et-ateliers-dartistes-a-visiter-a-paris/ Auditorium (n.m) ruang pagelaran music atau teater https://www.opera-bordeaux.com/auditorium-national-opera-bordeaux

B

Baguette (n.f) roti Prancis yang berbentuk tongkat https://kumparan.com/kumparanfood/5-cara-unik-menyantap-roti-baguetteala-warga-prancis-27431110790546838

Bar (n.m) bar https://www.happybeertime.com/blog/2018/07/05/top-100-des-meilleursbars-a-biere-de-france/

Bonneterie (n.f) pabrik/tempat penjualan pakaian rajutan

https://www.europages.fr/entreprises/France/Fabricant\%20Producteur/bonne terie.html

http://chanteclair.fr/

Boulangerie (n.f) tempat penjualan roti; pabrik roti

https://blog.france-langue.fr/top-10-des-meilleures-boulangeries-patisseriesde-france/

C

Cascade (n.f) air terjun

https://www.campingsluxe.fr/blog/top-20-plus-belles-cascades-de-france

Château (n.m) kastil

https://notrebellefrance.com/les-20-plus-beaux-chateaux-de-france

$\mathbf{E}$

Éclair (n.m) kue sus berbentuk panjang

https://www.tripadvisor.fr/LocationPhotoDirectLink-g293732-d12280718i250786064-Maison Amande Miel-

Casablanca Grand Casablanca Region.html

Escargot (n.m) bekicot

https://www.france-hotel-guide.com/fr/blog/restaurants-escargots-paris/

Exposition (n.f) pameran

https://www.france.fr/fr/actualite/liste/les-expositions-a-ne-pas-manquer-enfrance-en-2019

$\mathbf{F}$

Fête (n.f) pesta; perayaan

https://www.bonjourdefrance.com/exercices/contenu/les-fetes-en-france.html Fontaine (n.f) air mancur 
https://www.guide-evasion.fr/nos-tops/top-10-des-plus-belles-fontainesfranaises/

G

Grotte (n.f) gua

https://www.familiscope.fr/dossiers/les-plus-belles-grottes-a-visiter-en-

france/

Gymnastique (n.f) olahraga senam

https://www.gymparis15.fr/

$\mathbf{H}$

Hameau (n.m) desa kecil (dekat hutan) www.hameauduprat.com, www.chateauversailles.fr/grands-formats/hameau-de-la-reine Haras (n.m) peternakan kuda ; padang rumput peternakan kuda www.normandie-tourisme.fr/decouvrir/les-incontournables/les-grandsincontournables/le-haras-du-pin-187-1.html

Historique (adj/n.m) (mengenai ) sejarah ; historis

https://www.france-voyage.com/tourisme/histoire-panorama.html

I

Île (n.f) pulau

https://www.detoursenfrance.fr/patrimoine/patrimoine-naturel/top-20-des-

plus-belles-iles-francaises-7904

https://www.edreams.fr/blog/top-15-plus-belles-iles-francaises-instagram/

Îlot (n.m) pulau kecil

https://www.campinglesilotsdestval.com/campsite-france-centre-eure-et-

loir.html

$\mathbf{J}$

Jardin (n.m) kebun

http://www.notrebellefrance.com/v5/fr/les-plus-beaux-sites-de-france/les-15-

plus-beaux-jardin-de-france

$\mathbf{K}$

Kayac (n.m) perahu kayak

https://blog.yakaygo.com/ou-faire-du-canoe-kayak-en-france

Kouglof kugelhof (n.m) nama jenis kue dari daerah Alsace

https://www.recettes-alsace.fr/kougelhopf-kouglof/

$\mathbf{L}$

Lac (n.m) danau;telaga 
https://www.campingsluxe.fr/blog/top-20-plus-beaux-lacs-de-france Lagune (n.f) laguna;danau pantai https://www.eaufrance.fr/les-estuaires-lagunes-et-deltas

$\mathbf{M}$

Marché (n.f) pasar

http://www.google.com/amp/s/www.guide-evasion.fr/nos-tops/les-marchesde-france/amp/

Monument (n.m) monument;tugu peringatan

https://www.familiscope.fr/dossiers/top-30-des-plus-beaux-monuments-avisiter-en-france/

$\mathbf{N}$

Natation (n.f) renang

http://www.google.com/amp/s/amp.guide-piscine.fr/s-entrainer-etprogresser/competitions-de-nage/les-championnats-de-france-de-natation$4435 \mathrm{~A}$

Navire (n.m) kapal;bahtera http://francefluviale.fr

Noël (n.m) natal

http://fr.petitsfrenchies.com/les-traditions-de-noel-en-france/

Sedangkan untuk tampilan data korpus tersebut secara daring adalah sebagai berikut.

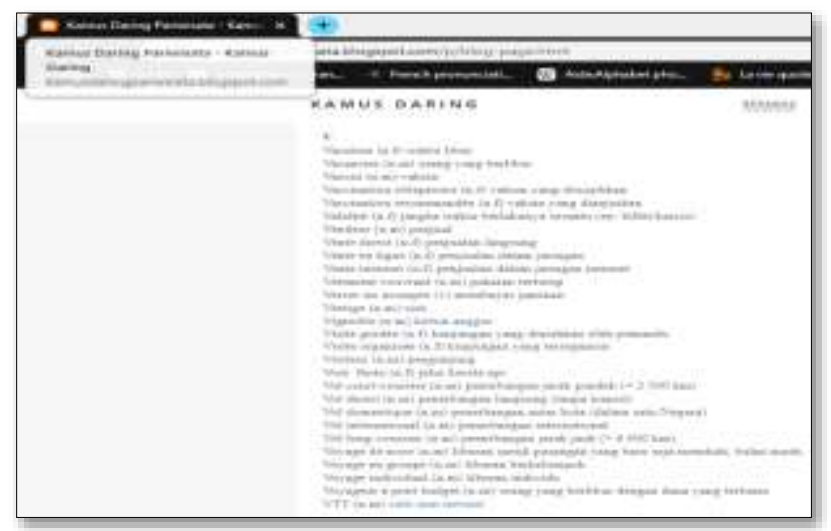

Gambar 1. Tampilan data korpus di dalam kamus daring

Berdasarkan tampilan korpus di atas, terdapat kosakata yang berwarna biru muda. Kosakata tersebut mengindikasikan bahwa ada link/informasi lebih lanjut terkait kosakata tersebut yang dapat diakses oleh pengguna hanya dengan mengklik kosakata yang berwarna biru muda tersebut. Misalnya kosakata VTT, setelah kosakata tersebut diklik, maka akan muncul situs/informasi seperti di bawah ini. 


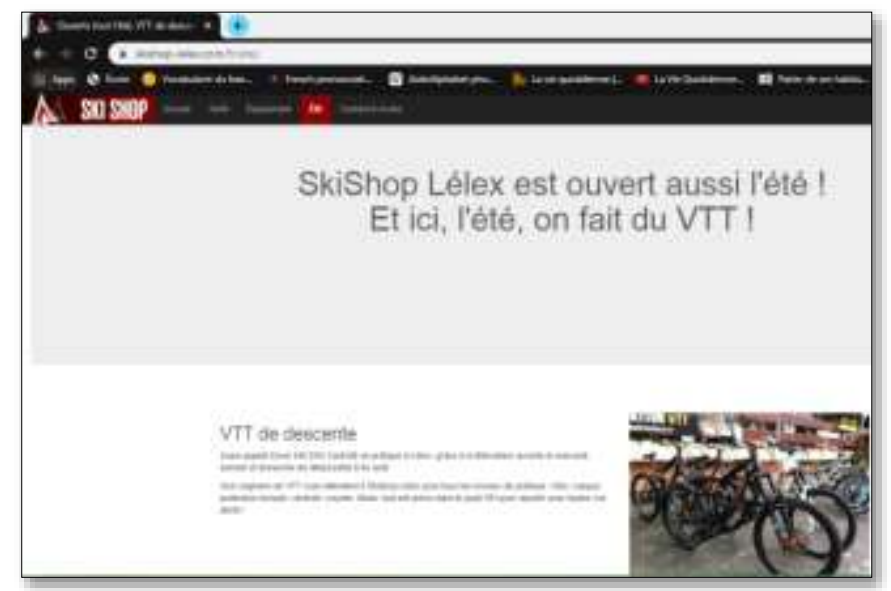

Gambar 2. Tampilan link/situs dari kosakata VTT setelah diklik

\section{Penyempurnaan tampilan kamus daring berbasis blog}

Kamus daring bidang pariwisata bahasa Prancis-Indonesia berbasis blog interaktif dapat diakses disitus www.kamusdaringpariwisata.blogspot.com. Tampilan kamus, konten dan kecanggihan menu yang ditampilkan dan yang dapat digunakan serta diakses oleh pengguna sudah lebih baik dibandingkan kamus daring tahun sebelumnya. Meskipun demikian, masih ada banyak hal yang perlu ditambahkan dan disempurnakan yang tentu saja membutuhkan modal yang tidak sedikit. Oleh karena itu, keberadaan kamus ini daring ini tentu saja terus memnbutuhkan pembaharuan dan perbaikan dari segala aspek.

Adapun tampilan kamus daring yang dimaksud adalah sebagai berikut.

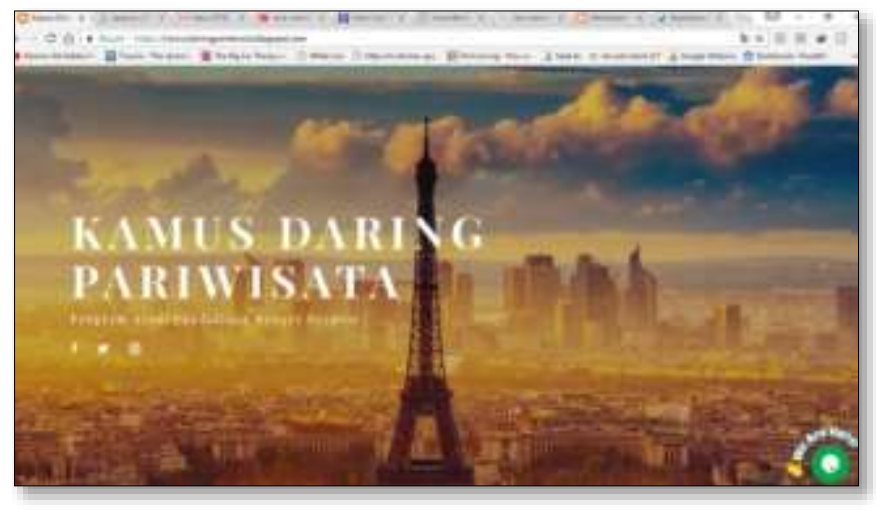

Gambar 3. Tampilan kamus daring pariwisata

Dengan demikian, kamus daring bahasa Prancis-Indonesia bidang pariwisata berbasis blog interaktif tersebut dapat digunakan oleh pengguna dengan lebih efektif dan fleksibel. Terdapat lebih banyak konten (data korpus 
kosakata) dan juga dilengkapi dengan informasi tambahan berupa link. Selain itu, pengguna dapat berkonsultasi atau bertanya sesuatu yang belum dipahami dengan meninggalkan pesan atau mengisi kolom komentar yang tersedia di menu bloh tersebut. Oleh karena, era Revolusi Industri 4.o benar-benar dapat disambut dengan penuh sukacita dan kreativitas oleh para generasi muda dan para pembelajar bahasa asing pada khususnya. Para pembelajar siap menjadi masyarakat Society 5.0.

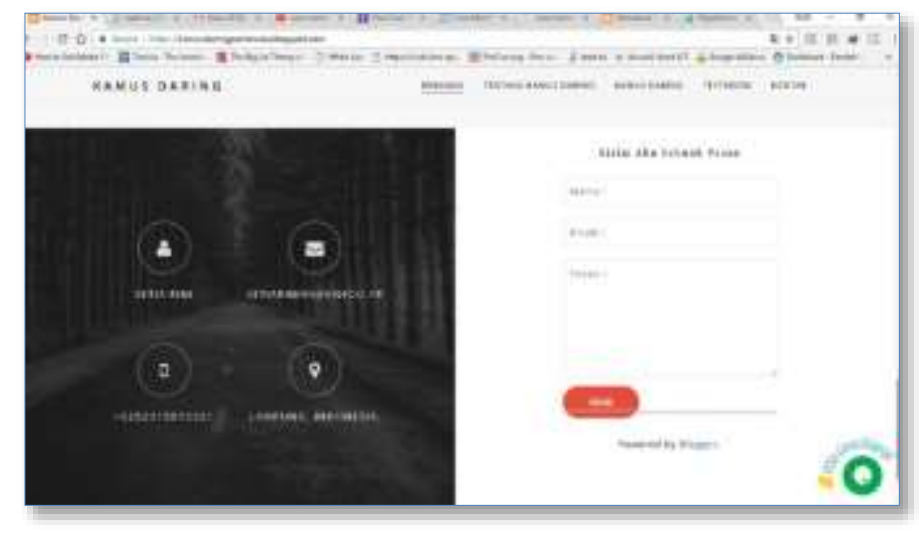

Gambar 4. Menu interaktif kamus daring

\section{Saran}

Adapun saran berdasarkan hasil penelitian ini adalah sebagai berikut.

1. Mahasiswa maupun dosen dapat menggunakan sekaligus memanfaatkan kamus daring tersebut khususnya dalam mata kuliah di bidang pariwisata.

2. Peneliti selanjutnya dapat menyempurnakan kekurangan-kekurangan dalam penelitian ini sehingga akan diperoleh hasil yang lebih maksimal.

3. Siapapun dapat menggunakan kamus daring ini sebagai media pembelajaran bahasa Prancis di bidang Pariwisata.

\section{Daftar rujukan}

Arikunto, S. (2002). Prosedur penelitian-suatu pendekatan Praktek. Jakarta : PT. Rineka Cipta.

Fauzi. (2010). Penggunaan model inkuiri dalam pembelajaran tata bahasa Perancis berbasis internet. (Tesis). Universitas Pendidikan Indonesia, Bandung.

Ghiffar, M. A. N., Nurisma, E., Kurniasih, C., \& Bhakti, C. P. (2018, May). Model pembelajaran berbasis blended learning dalam meningkatkan critical thinking skills untuk menghadapi era revolusi industri 4.o. In Prosiding Seminar Nasional STKIP Andi Matappa Pangkep (Vol. 1, No. 1, pp. 8594). 
Herriyance, H., Handrizal, H., \& Fadilla, S. D. (2017). Analisis algoritma rabinkarp pada kamus umum berbasis Android. Jurasik (Jurnal Riset Sistem Informasi dan Teknik Informatika), 2(1), 64-74.

Kamajaya, I., Moeljadi, D., \& Amalia, D. (2017). KBBI Daring: A revolution in the Indonesian lexicography. In Electronic lexicography in the 21st century. Proceedings of eLex 2017 conference (pp. 513-530).

Kurnia, A., \& Fitriyani, N. (2018, October). Pemanfaatan teknologi dalam proses pembelajaran pai di universitas mataram. In Prosiding Seminar Nasional II APPPI NTB 2018 (Vol. 1, No. 1).

Maemunah, M. (2018, September). Kebijakan pendidikan pada era revolusi industri 4.0. In Prosiding seminar nasional lembaga penelitian dan pendidikan (lpp) mandala.

Muhammad, Y. (2018). Era Industri 4.0: Tantangan dan peluang perkembangan pendidikan kejuruan Indonesia.

OMT. (2010). Le Champ du Tourisme. [Daring]. Diunduh di: https://archives.entreprises.gouv.fr/2012/www.tourisme.gouv.fr/stat et udes/memento/2010/memento2010-definitions.pdf

Qobt, H.A.A. (2008). Vers une didactique du Français sur objectifs spécifiques médié par Internet. [Daring]. Diunduh di : https://tel.archivesouvertes.fr/tel-00335245/document

Rachma, EPI. (2017). Peran linguistik korpus dalam penyusunan kamus di era modern. In Seminar Internasional Leksikologi dan Leksikografi.

Reginasari, A., \& Annisa, V. (2019). Menggali pengalaman menggunakan teknologi berbasis internet dalam mempersiapkan indonesia menuju industri 4.0. Jurnal Penelitian Kebijakan Pendidikan, 11(3), 183-196.

Rini, S., \& Rosita, D. (2019). Pengembangan kamus daring Prancis-Indonesia bidang pariwisata sebagai media pembelajaran interaktif program studi pendidikan bahasa Prancis FKIP Universitas Lampung. In Prosiding Seminar Nasional Pendidikan Fakultas Keguruan dan Ilmu Pendidikan 2019.

Risdianto, E. (2014). Rancang bangun aplikasi kamus digital fisika dengan microsoft visual basic 6.0 dan database Microsoft Access 2003. In Prosiding seminar nasional fisika (E-JOURNAL)(Vol. 3, pp. 37-42).

Santoso, D. B. (2009). Pemanfaatan Teknologi search engine optimazion sebagai media untuk meningkatkan popularitas blog Wordpress. Dinamik, 14(2).

Shofa, M. J. (2019, February). Peningkatan penggunaan media pembelajaran berbasis online untuk guru matematika di banten sebagai upaya menuju era industri 4.0. In Prosiding SNP2M (Seminar Nasional Penelitian dan Pengabdian Masyarakat) UNIM (No. 1, pp. 20-24).

Sugiyono. (2006). Statistika untuk Penelitian. Bandung: CV. Alfabeta.

Syamsuar, S., \& Reflianto, R. (2019). Pendidikan dan tantangan pembelajaran berbasis teknologi informasi di era revolusi industri 4.0. e-Tech: Jurnal Ilmiah Teknologi Pendidikan, 6(2).

Utami, A. D., Hardini, T. I., \& Mutiarsih, Y. (2019). Leksikografi kamus dwibahasa prancis-indonesia khusus bidang bisnis. Linguistik Indonesia, 37(1), 45-60. 
Viret, E. (2012). Français du tourisme, méthode de FOS destinée aux étudiants de l'université nationale du Laos. [Daring]. Diunduh di: https://emilieviret.files.wordpress.com/2012/01/methode-complete.pdf

Wahyudi, N. (2014). Pemanfaatan blog sebagai media pembelajaran interaktif. Jurnal Studi Islam: Pancawahana, 9(1), 85-94.

William. (2011). Pengertian kamus daring. http://williamkid.blogspot.com/2011/o4/pengertian-kamus-daring.html

https://kbbi.kemdikbud.go.id/entri/pariwisata

http://silabus.upi.edu/Direktori/FPBS/Pendidikan_Bahasa_Perancis/Silabus \%20\%26SAP\%20FdT\%202011.pdf 